\title{
Additions to the Neotropical species of the genus Eleusis LAPORTE, 1835 with description of new species (Coleoptera, Staphylinidae, Osorinae)
}

With 4 figures and 1 key

ULRICH IRMLER ${ }^{1}$

${ }^{1}$ Institute for Ecosystem Research, Dept. Applied Ecology, University of Kiel, Olshausenstrasse 110, 24098 Kiel, Germany. -
uirmler@ecology.uni-kiel.de
Published on 2019-06-24

DOI: 10.21248/contrib.entomol.69.1.071-077

\begin{abstract}
The Neotropical material of the genus Eleusis deposited in the Field Museum of Natural History, Chicago, USA, containing 440 specimens in 18 species, was studied. Additionally, specimens from French Guiana collected by J. Schmidl, Germany, were included. New records of eight rare species were listed and sampling details noted. Three new species were found: E. mazureki spec. nov., E. dybasi spec. nov., and E. chiriquensis spec. nov. The new species are described and integrated in the key to Neotropical Eleusis provided by IrMLER (2017). Furthermore, corrections to the same paper are necessary. These are: Eleusis platysoma IrmLer, 2017 is transferred to the genus Inopeplus (Salpingidae); Eleusis fauveli IrmLER, 2017 is preoccupied by Eleusis fauveli FAGEL, 1957 and E. fauveliana new name proposed for the former, and the location of holotype deposition of E. rufipennis is added.
\end{abstract}

\section{Nomenclatural acts}

Eleusis mazureki spec. nov. - urn.lsid:zoobank.org.act:220D0CEA-75CB-4537-BA0D-D95752582D34

Eleusis dybasi spec. nov. - urn.lsid:zoobank.org.act:ED409CD2-1674-4C51-94AE-A2AB6D54B066

Eleusis chiriquensis spec. nov. - urn.lsid:zoobank.org.act: EA43287D-B203-42E1-8A45-C1AC74396519

\section{Key words}

Osoriinae, Neotropis, new species, new name, new records, taxonomic corrections

\section{Zusammenfassung}

Das neotropische Material der Gattung Eleusis aus dem Field Museum of Natural History, Chicago, USA, wurde untersucht. Es enthielt 440 Individuen aus 18 Arten. Zusätzlich wurden noch Individuen aus FranzösischGuyana, die von J. Schmidl, Deutschland gesammelt wurden, einbezogen. Die neuen Funde von acht seltenen Arten werden aufgelistet und die Sammlungsdaten angegeben. Drei neue Arten wurden gefunden: E. mazureki spec. nov., E. dybasi spec. nov. und E. chiriquensis spec. nov. Die neuen Arten werden beschrieben und in den Bestimmungsschlüssel der neotropischen Eleusis Arten von IrmLer (2017) eingefügt. Weiterhin sind Berichtigungen für die Arbeit von Irmler (2017) notwendig. Diese sind: Eleusis platysoma Irmler, 2017 muss 
in die Gattung Inopeplus (Salpingidae) überführt werden; der Name Eleusis fauveli IrmLER, 2017 ist durch Eleusis fauveli FAGEL, 1957 besetzt und wird durch Eleusis fauveliana nom. nov. ersetzt. Außerdem wird der Ort der Lagerung des Holotypus von E. rufipennis ergänzt.

\section{Schlüsselwörter}

Osoriinae, Neotropis, neue Arten, neuer Name, neue Fundorte, taxonomische Ergänzungen

\section{Introduction}

After the publication of the review of Neotropical Eleusis LAPORTE, 1835, I received a large collection of the genus deposited in the Field Museum of Natural History, Chicago, USA. Among this material, three new species and several specimens of rarely found species were identified. Moreover, A. Newton drew my attention to several mistakes made in the publication of IRMLER (2017). The purpose of the present study is to describe the new species, list the new records of the rare species and to clarify the mistakes.

\section{Material and methods}

The material studied in this investigation is deposited in the Field museum of Natural History, Chicago, U.S.A. (FMNH) and in my own collection, the latter will be transferred to Senckenberg Deutsches Entomologisches Institut (SDEI) in the near future.

Photographs were taken using a Makroskop M 420 (Wild, Herbrugg) in combination with a digital camera Leica EC3. CombineZ5 (Hadley 2006) was used to optimise depth of focus. Length was measured in the middle of tagmata: head from clypeus to posterior edge, pronotum from anterior to posterior edge along midline, elytra from anterior edge at humeral angles to posterior edge; width at the widest part of tagmata (head width includes eyes). In the measurement of total length, the abdominal intersegmental space is subtracted.

\section{Results}

\section{Corrections}

\section{Inopeplus platysoma (IRMLER, 2017) new combination}

Eleusima platysoma IRMLer, 2017

Remarks: A. Newton advised me of a mistake regarding the genus Eleusima described in IrmLer (2017). The species described there as Eleusima, a genus of Eleusini of the family Staphylinidae, belongs to the genus Inopeplus, which is a genus of the family Salpingidae.

\section{Eleusis fauveliana new name}

Isomalus tenuis FAUveL, 1864: 41. Junior secondary homonym of Eleusis tenuis WALKER, 1859

Eleusis fauveli IRMLER, 2017: 282. Junior primary homonym of Eleusis fauveli FAGEL, 1957

New records: French Guiana: Maripassoula, Lawa River, under bark, 7.12.1963, leg. B. Malkin (FMNH); Maroni, male, leg. Moult (FMNH); Colombia: Putumayo, Santa Rosa de Sucumbios, Rio San Miguel, under bark of log, 400 m elev., female, 1.-7.9.1971, leg. B. Malkin (FMNH); Ecuador: Pastaza Prov., Cusuimi, Rio Cusuimi, 150 km SE Puyo, $300 \mathrm{~m}$ elev., 3 males, 6 females, 19.-23.7.1971, leg. B. Malkin (FMNH); Peru: Sivia, Flußbett, an alten Baumstämmen, 520 m elev., female, 1956, leg. Sammelreise Hmbg. Museum (FMNH); Bolivia: Dept. Santa Cruz, Prov. Ichilo, "Cafetal", forest, under bark of log, female, 6.8.1990, leg. P. Parillo (FMNH).

Remarks: A. Newton advised me of a mistake concerning E. fauveli IrmLer, 2017. This name is preoccupied by Eleusis fauveli FAGEL, 1957 from South Africa. Thus, a new name is needed for the South American species, which should be E. fauveliana.

\section{Eleusis rufipennis IRMLER, 2017}

Remarks: In the description of E. rufipennis in IRMLER (2017) the depository of the holotype was not fixed. It is the same as given for the paratypes, the Snow Entomological Collections of the University of Kansas, Museum of Natural History, Lawrence, Kansas, U.S.A.

\section{New records of rarely found species}

\section{Eleusis adusta (FAUvEL, 1864)}

Brazil: Nova Teutonia, 2 females, 26.7.1938 leg. F. Plaumann (FMNH); Rio de Janeiro, female, coll. Fry (FMNH); Apiai, São Paulo, 24.1.1903, leg. Krong (FMNH).

Remarks to distribution: The new records support the known distribution of E. adusta (FAUveL, 1864). In addition to the records known from Belém to Rio de Janeiro and Paraguay (IrMLER, 2017), the species is distributed farther south down to the state of Santa Catarina, Brazil. 
The main distribution may be in the Atlantic rainforest region. Unfortunately, due to the restrictive collection laws of Brazil only old records are known.

\section{Eleusis boliviana IRMLER, 2017}

Peru: Cuzco Dept., Consuelo, Manu rd. km 165, palm litter, bamboo shoots, 4 males, 3 females, 11.10.1982, leg. L.E. Watrous \& G. Mazurek (FMNH).

Remarks to distribution: In the description of the species IRMLER (2017) mentioned only the 4 type specimens, which were all collected from Villa Tunari, Bolivia, using a flight intercept trap. The specimens from the Field Museum of Natural History originated from only one location at Manu National Park, Peru. The new location is about $650 \mathrm{~km}$ north of the Bolivian records but in the same elevation zone of the eastern Andean slope.

\section{Eleusis castanea IRMLER, 2017}

Costa Rica: Vara Blanca, $2000 \mathrm{~m}$ elevation, male, 15.8.1938, leg. A. Bierig (FMNH).

Remarks to distribution: IRMLER (2017) only mentioned the male holotype from Colombia sampled by a Malaise trap. Within the material of FMNH a second male specimen was found from Costa Rica, which shows that the species has a wider distribution at least from Columbia to Costa Rica. Nevertheless, the record of only a single second specimen reveals that the species is extremely rare in the region.

\section{Eleusis frater (FAUvEL, 1864)}

Ecuador: Napo, $44 \mathrm{~km} \mathrm{~N}$ Tena, female, 29.4.1978, leg. L. \& C.W. O'Brien, \& G.B. Marshall (FMNH); French Guiana: FG - Amazonia, Mitaraka $\left(2^{\circ} 14.2^{\prime} \mathrm{N}, 54^{\circ} 27.1^{\prime} \mathrm{W}\right)$, male, 6.3.2015, leg. J. Schmidl (UIC).

Remarks to distribution: Only few specimens are known from this species. Eleusis frater seems to be rare but has a wide distribution. The records cover a large area from French Guiana in the West to Ecuador and Peru in the East and from Venezuela in the North to Espiritu Santo, Brazil, in the South. Thus, the species seems to be distributed all over the lowland rain forest area from the Guianas and the entire Amazonian lowland rainforest up to the western Andean slope.

\section{Eleusis hondurana IRMLER, 2017}

Mexico: Oaxaca, $4.5 \mathrm{mi} \mathrm{S}$ Valle Nacional, under bark of tropical hardwood, $1600 \mathrm{ft}$ elevation, 2 males,
13.-16.8.1973, leg. A. Newton (FMNH); same location, same collector, but $5.1 \mathrm{mi}$ S Valle Nacional, female, 11.-18.8.1973 (FMNH).

Remarks to distribution: According to IrmLer (2017) only the holotype was known, originating from Honduras. Three further specimens were found in the collection of the Field Museum of Natural History that were collected in Oaxaca, Mexico. The new locality shows that the species may be rare but has a wider distribution in the area from central Honduras to southern Mexico.

\section{Eleusis insignis SHARP, 1887}

Guatemala: Yepocapa, Chimal. $4800 \mathrm{ft}$. elev., male, 27.4. 1948, leg. R.L. Wenzel (FMNH).

Remarks to distribution: Like the few specimens listed before in IRMLER (2017), the new specimen of E. insignis SHARP, 1887 originated from Guatemala. Regarding the elevation level, the species lives in areas between $1500 \mathrm{~m}$ and $2500 \mathrm{~m}$.

\section{Eleusis panamaensis IRMLER, 2017}

Panama: Canal Zone, Barro Colorado Is., under fermenting bark, 1 male, 2 females, 16., 22.2.1976, leg. A. Newton (FMNH).

Remarks to distribution: In IRMLER (2017) only the two type specimens are listed. In the Field Museum of Natural History three additional specimens were found, collected on Colorado Island in the Panama channel. As the two type specimens also originated from the same province in Panama, it seems that the species is endemic in a small area of Panama.

\section{Eleusis rufipennis IRMLER, 2017}

Mexico: Oaxaca, $14 \mathrm{mi}$ S Suchixtepec $\left(16^{\circ} 05^{\prime} \mathrm{N}, 96^{\circ} 28^{\prime} \mathrm{W}\right)$, Hwy 175, montane tropical, $1700 \mathrm{~m}$ elev., under bark fermenting sap, male, 30.4.1977, leg. J.S. Ashe, \#FMHD77399 (FMNH).

Remarks to distribution: According to IRMLER (2017) only the two type specimens were known, which originated from Costa Rica. The new specimen from Mexico seems to be identical with these specimens concerning the aedeagus, size and coloration but differs slightly in the shape of the head. The head is slightly more elongate with longer postocular space. However, due to the overall infraspecific variability of the head shape in the genus, the specimen was identified as E. rufipennis Irmler, 2017. Thus, the species seems to be rare but widely distributed from southern Central America to the tropical areas of Mexico. 


\section{Descriptions of the new species}

\section{Eleusis mazureki spec. nov.}

urn.Isid:zoobank.org.act:220D0CEA-75CB-4537-BA0D-D95752582D34

Figs $1 \mathrm{a}-\mathrm{c}, 4 \mathrm{~A}$

Type material: Holotype, male: Peru, Dept. Consuelo, Manu rd. km 165, 12.10.1982, leg. L.E. Watrous \& G. Mazurek, \#FMHD 82-373 (FMNH). Paratypes: Peru: Cuzco Dept., Consuelo, Manu rd. km 165, rotten palm \& leaf litter, male, female, 1.10.1982, leg. L.E. Watrous \& G. Mazurek, \#FMHD 82-313; same location and collectors, 2 females, \#FMHD 11.10.1982 (3 FMNH, 1 UIC).

Diagnosis: The species is part of the E. bicolor group of the Neotropical Eleusis species due to the shape of the pronotum with smoothly rounded sides, not interrupted by a short emargination behind the middle. Front angles with groove and one setiferous puncture adjacent at inner margin. It mostly resembles E. frater (FAuveL, 1864) and E. panamensis IRMLER 2017 in size and coloration. While the head of E. frater (FAUveL, 1864) has polished parts on the head and E. panamaensis IrMLER, 2017 has contiguous weak microsculpture, E. mazureki spec. nov. has dense and deep microsculpture with matt surface. Furthermore, the elytra are lighter yellowish, the head is more elongate with longer postocular space, and the shape of the aedeagus is distinctly different from that of both species.

Description: Length: $4.2 \mathrm{~mm}$. Coloration: Dark blackish brown; elytra lighter yellowish in anterior half; abdomen lighter brown than head and pronotum; legs and antennae light brown.

Head: $0.64 \mathrm{~mm}$ long, $0.62 \mathrm{~mm}$ wide; eyes not prominent; shorter than postocular space; postocular sides slightly divergent to rounded posterior angles and 1.3 times as long as eyes; neck distinct; preocular sides shortly parallel to base of antennae; anterior margin of clypeus strongly convergent to straight central part; supraocular groove long and deep with two setiferous punctures at each end of the groove; more setiferous punctures along anterior margin of clypeus; two deep round depressions on central part between eyes; normal punctation deep and moderately sparse; interspace between punctures two to four times as long as diameter of punctures; microsculpture deep and dense; reticulation elongate; surface matt.

Antennae as long as head and half of pronotum combined; first antennomere longer and thicker than following antennomeres; second antennomere only half as long as first; third antennomere triangular, only slightly shorter than first; following antennomeres decreasing in length and slightly increasing in width; fourth antennomere longer than wide; tenth antennomere wider than long; eleventh antennomere nearly twice as long as wide; fourth to eleventh antennomere with yellow setae.

Pronotum: $0.52 \mathrm{~mm}$ long, $0.60 \mathrm{~mm}$ wide; sides approximately parallel in anterior half; strongly convergent in posterior half; at anterior angles with groove separated by carina from a second round groove at inner anterior margin; inner round groove with setiferous punctures; outer groove at angle with setiferous puncture posteriad; another setiferous puncture in posterior half at lateral margin; along anterior and posterior margin few further setiferous punctures; normal punctation as dense and deep as on head; microsculpture similar as on head but only elongate reticulate on central disc; at angles and along sides wavy reticulate; surface matt.

Elytra: $0.50 \mathrm{~mm}$ long, $0.66 \mathrm{~mm}$ wide; sides divergent to posterior angles; humeral angles distinct; shortly rounded; posterior angles rounded; posterior margin slightly curved with weak incision at suture; one setiferous puncture on central disc; few more setiferous punctures along lateral margin; normal punctation as dense and deep as on head and pronotum; micro-sculpture similarly deep and dense as on head and pronotum an with elongate reticulation; surface matt.

Abdomen with weak transverse reticulate microsculpture; punctation weaker and sparser than on forebody; surface shiny.

Aedeagus in lateral aspect with central lobe curved; with distinctly sclerotized ventral plate; on central part of ventral plate with slight prominence; apex triangularly widened; prominence with several sensillae; further sensillae adjacent to prominence; no endophallic structures visible; in ventral aspect, central lobe elongate with convergent apex; row of sensillae along midline and few further sensillae adjacent to it; parameres shorter than central lobe; slender; widened to transparent lobe at apex; transparent lobe with few micro-sensillae and one short seta.

Etymology: The species name honours one of the collectors who found it during his extensive collections in South America.

\section{Eleusis dybasi spec. nov. urn.Isid:zoobank.org.act:ED409CD2-1674-4C51-94AE-A2AB6D54B066 Figs 2a-c, 4B}

Type material: Holotype, male: Panama, Chiriqui Prov., nr. Nueva California, W of Finca Palo Santo, in torn fibers of wounded tree, $5000 \mathrm{ft}$., 10.3.1959, lg. H. Dybas (FMNH). Paratypes: male, same location, collector and date as holotype; 2 males, same location and collector as holotype, but 9.3.1959; Chiriqui Prov., Finca Lerida nr. Boquete, in split sapling, $5650 \mathrm{~m}$ elev., male, 14.3.1959, leg. H. Dybas (3 FMNH, 1 UIC).

Diagnosis: Eleusis dybasi resembles E. humilis (ERICHSON, 1840) and E. fauveliana in size, colouration and in the shape of the aedeagus. On average, it is slightly larger than E. fauveliana and the central prominence of the aedeagus is more distinct, as in E. humilis. The elongate elytra are the most specific character. In E. humilis and 
E. fauveliana the elytra are quadrate or slightly shorter than wide, whereas in E. dybasi the elytra are longer than wide (ratio: 1.15).

Description: Length: $2.6 \mathrm{~mm}$. Colouration: Blackish to dark brown; elytra light yellow with indistinct infuscate apex; abdomen lighter brown than head and pronotum; legs and antennae light brown; base of antennae yellowish.

Head: $0.31 \mathrm{~mm}$ long; $0.33 \mathrm{~mm}$ wide; eyes large, slightly prominent; approximately twice as long as postocular space; widely rounded to neck; preocular sides parallel; as long as postocular space; sides slightly divergent from base of antennae to posterior angles; sides of clypeus shortly sinuate; narrowed to straight anterior margin; supraocular groove short with setiferous puncture on each end; two additional setiferous punctures at sinuate part of clypeus; punctation moderately sparse and deep; interstices between punctures varying; on average three to five times as wide as diameter of punctures; microsculpture distinct; on vertex approximately longitudinally striate; on clypeus and neck transversely striate; surface moderately shiny; posterior angles without microsculpture; surface nearly polished.

Antennae: first antennomere thicker than four following antennomeres; second antennomere one third shorter than first, approximately as long as conical third antennomere; following antennomeres increasing in width and decreasing in length; fourth antennomere longer than wide; tenth antennomere wider than long; antennomeres four to eleven pubescent and with long yellow apical setae.

Pronotum: $0.30 \mathrm{~mm}$ long; $0.33 \mathrm{~mm}$ wide; widest close to anterior angles; anterior angles widely rounded; sides strongly convergent posteriad; space between anterior angles nearly twice as wide as between posterior angles; lateral sides at central convergent part deeply interrupted; interruption marked by setiferous puncture; along lateral, anterior and posterior margins with additional setiferous punctures; with pair of large deeply depressed punctures close to anterior angles at anterior margin; punctation similarly deep and sparse as on head; microsculpture similarly distinct as on head; longitudinally striate on central disc; wavily striate close to anterior angles; surface moderately shiny.

Elytra: $0.45 \mathrm{~mm}$ long, $0.39 \mathrm{~mm}$ wide; humeral angles distinct; sides slightly divergent posteriad; posterior angles widely rounded; posterior margin smoothly rounded with slight incision at suture; one larger setiferous puncture on central disc; several more setiferous punctures along lateral margin; punctation slightly deeper but similarly sparse as on head and pronotum; microsculpture as deep and dense as on head and pronotum; longitudinally striate; surface moderately striate.

Abdomen sparsely punctate; microsculpture transversely striate.

Aedeagus with central lobe in lateral aspect moderately thick with acute apex; slightly rounded; at inner side straight with weak central prominence; in ventral aspect wide; prominence narrow with numerous sensillae; more sensillae close to prominence but nearer to base; paramere distinctly shorter than central lobe; moderately thick with wide apical transparent lobe; transparent lobe with numerous micro-sensillae and with short seta at apex.

Etymology: The species name honours the collector H. Dybas, who collected extensively in South and Central America.

\section{Eleusis chiriquensis spec. nov. urn. Isid:zoobank.org.act: EA43287D-B203-42E1-8A45-C1AC74396519 Figs. 3a-c, 4C}

Type material: Holotype, male: Panama: Chiriqui Prov. "Barca" area, Finca Lerida near Boquete, under slab on pile of cut chips and bark, $5650 \mathrm{ft}$. elev., 12.3.1959, leg. H.S. Dybas (FMNH). Paratype: male with same data as holotype (FMNH):

Diagnosis: Eleusis chiriquensis resembles E. dybasi by the elongate elytra and, thus, can easily be differentiated from the other species related to E. humilis. With a length : width ratio of 1.19 , the elytra are still longer than in E. dybasi. Additionally, it is slightly larger, colouration is lighter and the aedeagus is thicker.

Description: Length: 2.8. Colouration: Head brown; pronotum light brown; elytra still lighter brown to dark yellow; abdomen light brown; legs and antennae light brown to yellowish.

Head: $0.36 \mathrm{~mm}$ long, $0.42 \mathrm{~mm}$ wide; eyes large and slightly prominent; postocular space divergent; short, 0.6 times as long as eyes; parallel preocular space as long as postocular space; sides of clypeus sinuate; front margin of clypeus straight; supraocular groove short with setiferous puncture at each end; further setiferous punctures at base of antennae and close to front margin of clypeus; punctation moderately deep and sparse; interstices between punctures varying; on average, two to three times as wide as diameter of punctures; microsculpture moderately deep; on vertex, longitudinally striate; surface shiny.

Antennae: first antennomere thicker than following three antennomeres; second two thirds as long as first; third not longer than second; following antennomeres decreasing in length and increasing in width; fourth antennomere longer than wide; tenth antennomere wider than long; antennomeres four to eleven pubescent and with yellow apical setae.

Pronotum: $0.33 \mathrm{~mm}$ long; $0.38 \mathrm{~mm}$ wide; widest close to anterior angles; anterior angles widely rounded; sides strongly convergent posteriad; at posterior angles 0.6 times as long as at anterior angles; lateral interruption deep; marked by setiferous puncture; few more setae anteriad to interruption and at ante- 
1

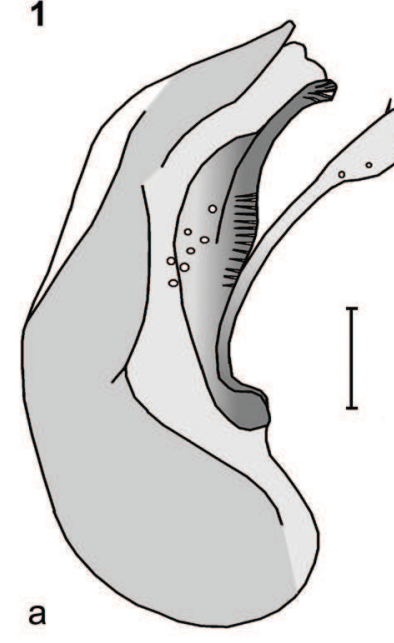

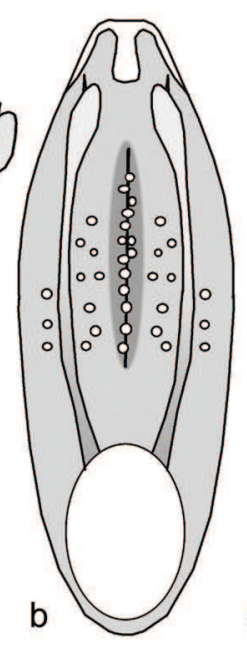
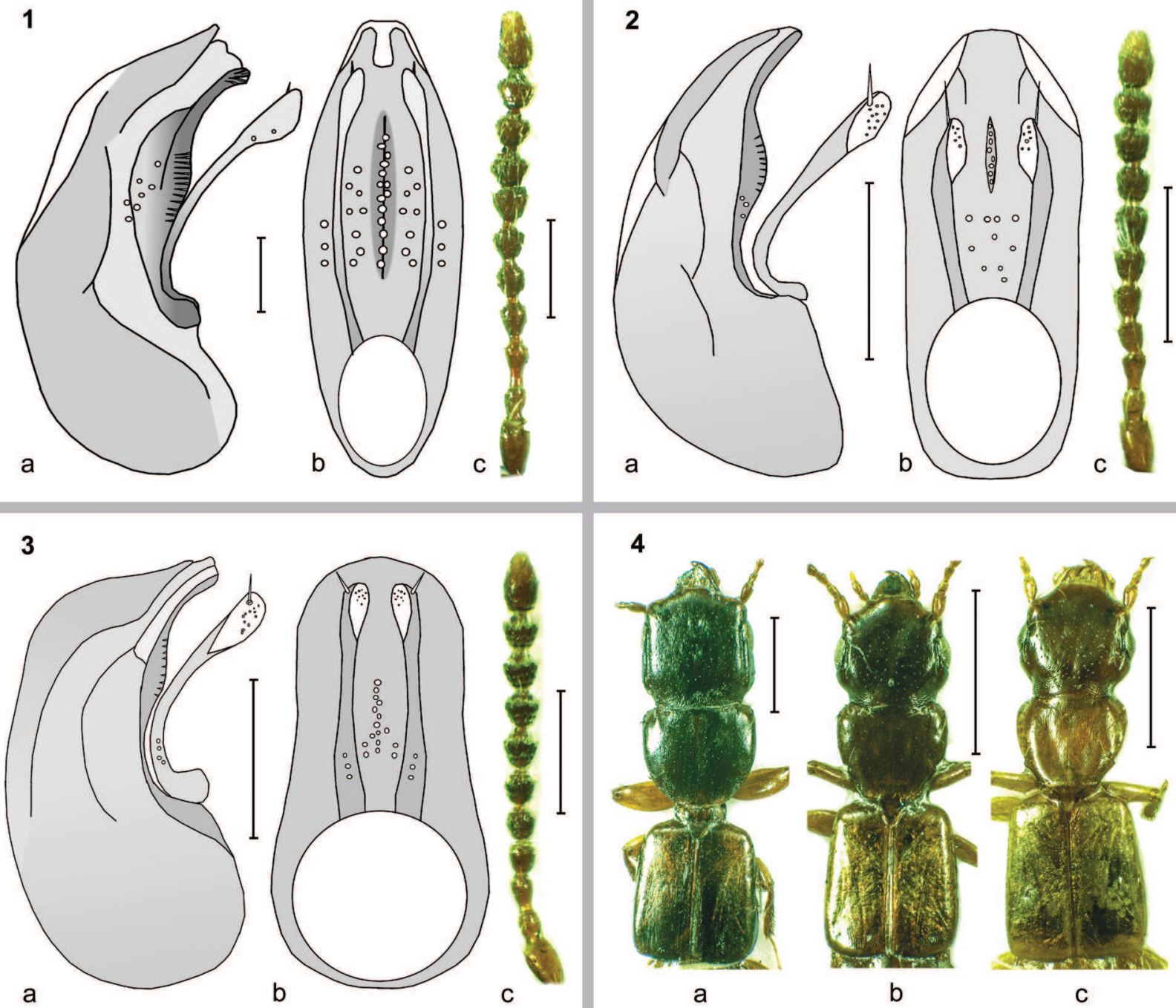

b

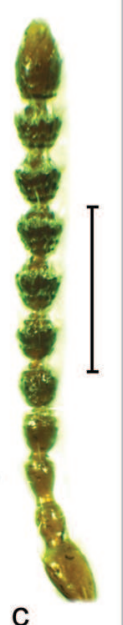

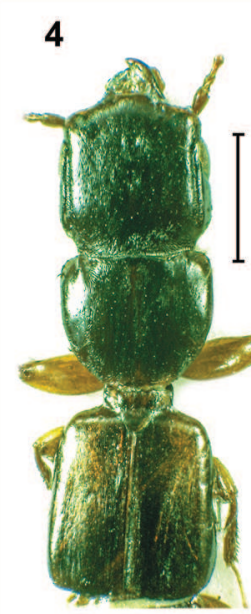

a

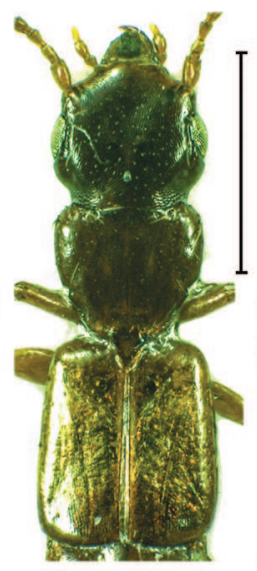

b

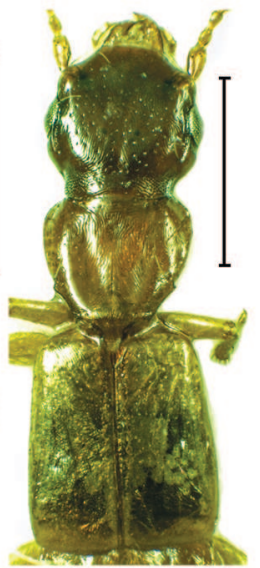

C

Figs 1-3: Eleusis mazureki (1), E. dybasi (2), E. chiriquensis (3); aedeagus lateral (a) and ventral (b) aspect, antenna (c); scale bar $0.1 \mathrm{~mm}$. - Fig. 4: Forebody showing shape and colouration of Eleusis mazureki (A), E. dybasi (B), E. chiriquensis (C); scale bar, $0.5 \mathrm{~mm}$.

rior margin; week furrow at midline in posterior half; weak depressions laterad to furrow; punctation similar to that on head; slightly sparser; on average interstices between punctures three times as wide as diameter of punctures; microsculpture similar to that on head; on disc longitudinally striate; laterally wavily striate; surface shiny.

Elytra: $0.58 \mathrm{~mm}$ long, $0.49 \mathrm{~mm}$ wide; elytra transparent; with distinct humeral angles; slightly divergent to posterior angles; posterior angles distinct; nearly rectangular; posterior margin straight; one setiferous puncture on disc; punctation and microsculpture weaker than on pronotum; surface shiny.

Abdomen: sparsely punctate; weak microsculpture transversely striate.

Aedeagus with central lobe broad in lateral aspect, most parts of central lobe equally thick; close to apex abruptly narrowed to thick apex; inner side of central lobe with weak prominence along midline; prominence marked by numerous sensillae; a few more sensillae closer to base; parameres nearly as long as central lobe; with moderately wide transparent lobe at apex; transparent lobe with numerous micro-sensillae and with apical seta.

Etymology: The species name is derived from the Panama province Chiriqui, where it was collected.

\section{Discussion}

Among the 440 specimens found in the material of the Field Museum of Natural History, 17 species were identified. The most common species was E. scita with 152 specimens, because the sampling efforts of the museum concentrated on Panama, where E. scita SHARP, 1887 is one of the most common Eleusis species. The next common species was E. bicolor from various Central American countries with 75 specimens in total. The remaining species were collected in only few speci- 


\section{Corrected key to the Neotropical Eleusis species}

5 Elytra distinctly longer than wide (length : width ratio between 1.09-1.19), light reddish brown with dark spot along suture or pale with indistinct obscuration

- Elytra approximately quadrate, slightly wider than long or slightly longer than wide (length : width ratio 0.96-1.07), elytra dark brown without darker spot or pale with darker posterior margin and sides

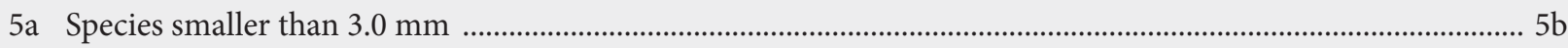

- $\quad$ Larger species of at least $3.8 \mathrm{~mm}$ length

5b Slightly larger, $2.8 \mathrm{~mm}$ long, pronotum lighter, and aedeagus with curved apex E. chiriquensis spec. nov.

- Slightly smaller, $2.6 \mathrm{~mm}$ long, pronotum darker, and aedeagus with straight apex E. dybasi spec. nov.

17 Totally black

- Only partly black, variable in coloration, but never totally black $18 \mathrm{a}$

18 Head with dense microsculpture and without punctation E. panamaensis IRMLER, 2017

Head with polished parts and distinctly punctate E. frater (FAUVEL, 1865)

18a Small species of $4.2 \mathrm{~mm}$ length with dark pronotum and lighter elytra E. mazureki spec. nov.

- Larger species of at least $4.5 \mathrm{~mm}$ length or if smaller, pronotum light reddish 19

mens. The new records of eight rare species known only from very few locations show that some of them have a wider distribution than presumed from the previously known locations. In particular, E. rufipennis IRMLER, 2017 has a wider distribution at least from Costa Rica to Mexico and E. castanea Irmler, 2017 from Colombia to Costa Rica. Some other sampling points of rare species support the restricted distribution supposed by IRMLER (2017). For example, E. panamaensis IRMLER, 2017 was found in several specimens from the same narrow region in Panama noted by IRMLER (2017) or E. insignis SHARP, 1887, which was also found in the small region along the border between Mexico and Guatemala. The findings of two new species from Panama document that southern Central America is one of the hot spots in Neotropical Eleusis species richness with actually 12 species. Furthermore, the new species E. mazureki spec. nov., supports the assumption of IrMLER (2017) that more new Eleusis species will also found in the eastern Andean range.

\section{Acknowledgements}

I thank Dr. Crystal Meyer and Dr. Alfred F. Newton for their support to loan the Eleusis material of their museum and for allowing me to retain several specimens for my collection. I also thank Dr. Jürgen Schmidl from the Department of Biology of the University of ErlangenNürnberg, Germany, who loaned his Osoriinae material collected by him in French Guiana and delivered one specimen of $E$. frater for my collection.

\section{References}

FAGEL, G. 1957: Contribution à la connaissance des Staphylinidae, XLVII. Notes sur quelques Eleusis éthiopienes. - Revue de Zoologie et de Botanique Arfricains 56: 189-202.

Fauvel, A. 1864: Études sur les staphylinides de l'Amerique centrale, principalement du Mexique. Notices Entomologique 2: 3-62.

Hadley, A. 2006: Combine Z5.3. Public Domain software.

Irmler, U. 2017: The Neotropical species of the genus Eleusis LAPORTE, 1835 with description of the new genus Eleusima (Coleoptera: Staphylinidae: Osoriinae). - Contributions to Entomology 67: 275-318. - DOI: 10.21248/contrib.entomol. 67.2.275-318.

LAPORTE, F. L. 1835: Étude entomologique, ou description d'insects nouveaux, et observation sur les synonymie. - Méquignon-Marvais, Paris: $159 \mathrm{pp}$.

Sharp, D. 1887: Insecta. Coleoptera. vol. 1, pt. 2. - Godman, F. D. \& Salvin, O. (eds): Biologia Centrali-Americana: zoology, botany and archaeology. - Published for the editors by R. H. Porter, London: 870 pp. - DOI: 10.5962/bhl.title.730. - http:// www.biodiversity-library.org/item/14601\#page/7/ mode/lup [accessed 2017-06-20]. 